\title{
Perencanaan Partisipatif Menyusun Rencana Aksi Menanggulangi Perkawinan Usia Dini di Temanggung, Jawa Tengah
}

\author{
Setiadi, Atik Triratnawati, Suzie Handajani, Agung Wicaksono, Khidir M. \\ Prawirosusanto, Nurul Friska Dewi
}

Departemen Antropologi, Fakultas Ilmu Budaya, Universitas Gadjah Mada

Korespondensi: setiadi_antro@ugm.ac.id

\begin{abstract}
A Community Service Activity (PkM) are carried out by the Anthropology Department Team in Wonotirto Village, Temanggung Regency. Early marriage is still a challenge for quality family development. There is a fact that, for the target community, getting married at an early age is not a problem, while from a government perspective it is a serious problem, especially the adverse impacts on social, economic, and reproductive health aspects. Participatory solution of early marital problems is important to be made as a priority. Preliminary observations show that there are economic and cultural reasons that encourage someone to be married off at an early age. The PkM results several important things related to the condition of the community and their understanding of early marriage. First, in general, the community realizes the importance of more mature planning in preparing for the formation of a new family. Second, early marriages that occurred in the last decade were caused by pregnancy due to the promiscuity of children, the habit of watching porn videos, and dropping out of school while the previous decade was due to arranged marriages. Third, adolescents targeted by the program have committed to campaign for the prevention of early marriage. They post and disseminate messages on prevention of early marriage through the WA group. Fourth, young people want the facilitation for activities of post-school youth.
\end{abstract}

Keywords: Early marriage; participatory planning; community service

\begin{abstract}
Abstrak
Kegiatan Pengabdian kepada Masyarakat (PkM) dilakukan oleh Tim Departemen Antropologi di Desa Wonotirto, Kabupaten Temanggung. Pernikahan usia dini masih merupakan tantangan bagi pembangunan keluarga yang berkualitas. Ada fakta bahwa bagi masyarakat sasaran kegiatan, menikah pada usia dini bukan sebuah masalah, sementara dari perspektif pemerintah hal tersebut merupakan permasalahan serius, terutama dampak buruk dalam aspek sosial, ekonomi, dan kesehatan reproduksi. Penanganan secara partisipatif masalah perkawinan usia dini penting untuk dijadikan sebagai prioritas. Observasi awal menunjukkan adanya alasan ekonomi dan kultur yang mendorong seseorang dinikahkan pada usia dini. Tahapan-tahapan PkM menghasilkan beberapa hal penting terkait dengan kondisi masyarakat dan pemahaman mereka tentang perkawinan usia dini. Pertama, secara umum, masyarakat menyadari pentingnya perencanaan lebih matang dalam menyiapkan pembentukan keluarga baru. Kedua, perkawinan usia dini yang terjadi pada satu dasawarsa terakhir disebabkan oleh adanya kehamilan akibat pergaulan bebas anak-anak, kebiasaan menonton video porno, dan putus sekolah, sedangkan dasawarsa terdahulu akibat perjodohan. Ketiga, anak-anak remaja sasaran program telah berkomitmen mengampayekan pencegahan perkawinan usia dini. Poster dan pesan-pesan sosialisasi pencegahan perkawinan usia dini mereka sebarkan melalui grup
\end{abstract}


WhatsApp. Keempat, remaja menghendaki adanya fasilitasi kegiatan bagi remaja pascasekolah.

Kata Kunci: Perkawinan usia dini; perencanaan partisipatif; pengabdian kepada masyarakat

\section{Pendahuluan}

\section{Mengapa Isu Perkawinan Usia Dini di Desa Wonotirto Penting?}

Ada gap antara perspektif elemen-elemen pengambil kebijakan dan masyarakat lokal terkait dengan pernikahan usia dini. Bagi kelompok pertama, perkawinan usia dini dipandang sebagai hal yang tidak ideal karena menghilangkan hak anak/remaja untuk berkembang lebih baik, memunculkan permasalahan kesehatan reproduksi, meningkatkan potensi perceraian dalam keluarga muda, dan melanggar UU Perkawinan yang memberikan minimal usia tertentu untuk bisa menikah. Sementara itu, kelompok kedua tidak mempertimbangkan hal-hal demikian. Ketika tim membuka forum diskusi dengan tokoh masyarakat dan kepala keluarga di Desa Wonotirto, perkawinan usia dini bukanlah sebuah masalah. Bagi mereka, pernikahan usia dini merupakan fenomena biasa. "Anak-anak yang dilahirkan selalu sehat, ibu yang melahirkan juga sehat. Saya malah bisa mendapatkan cucu ketika masih muda dan menantu untuk bekerja di ladang," sergah seorang peserta diskusi.

Pandangan ini memperkuat fakta bahwa masalah perkawinan usia dini memang sulit untuk diatasi, mengingat aspek-aspek yang kompleks yang melingkupinya (Plan Indonesia (Jakarta) and Center for Population and Policy Studies, t.t.). Aspek-aspek kompleks tersebut seperti kemiskinan, proteksi terhadap anak perempuan, kehormatan keluarga, pemberian stabilitas sosial pada periode kesulitan tertentu, dan anggapan bahwa perkawinan anak merupakan solusi (UNICEF, 2005a:1). Dalam konteks Indonesia, dengan mengutip data publikasi Yayasan Kesehatan Perempuan 2015, hasil penelitian UNICEF di Indonesia tahun 2002, ditemukan angka kejadian pernikahan anak berusia 15 tahun berkisar 11\%, sedangkan yang menikah pada saat usia tepat 18 tahun adalah sekitar 35\%. Data lain menyebutkan bahwa angka perkawinan usia anak atau di bawah 18 tahun di Indonesia masih tinggi, yakni sekitar 23\% (Priherdityo, 2016). Dalam publikasi yang sama disebutkan bahwa merujuk data BPS dan UNICEF yang menggunakan data Susenas 2008-2012 dan Sensus Penduduk 2010, tercatat sekitar 340.000 anak perempuan di bawah 18 tahun menikah setiap tahunnya. Peningkatan terjadi pada perempuan usia antara $15-18$ tahun. Perempuan pada keluarga miskin memiliki kemungkinan dua kali lebih besar untuk menikah pada usia di bawah 18 tahun dibandingkan perempuan dari keluarga berpendapatan tinggi (UNICEF, 2010:47).

Pada hasil analisis Survei Penduduk Antar Sensus (SUPAS) 2005, mengutip data dari Badan Koordinasi Keluarga Berencana Nasional (BKKBN), didapatkan angka pernikahan di perkotaan lebih rendah daripada di area perdesaan, yakni 5,28\% di perkotaan dan $11,88 \%$ di perdesaan untuk kelompok umur $15-19$ tahun. Hal ini menunjukkan bahwa wanita usia muda di perdesaan lebih banyak melakukan perkawinan di usia muda. Meskipun pernikahan anak merupakan masalah predominan di negara berkembang, ada bukti bahwa kejadian ini juga masih berlangsung di negara maju, yang orang tua menyetujui pernikahan anaknya yang berusia kurang dari 15 tahun.

Data penelitian dari Pusat Kajian Gender dan Seksualitas Universitas Indonesia 
tahun 2015 lalu mengungkapkan bahwa angka perkawinan dini di Indonesia berada pada peringkat kedua teratas di kawasan Asia Tenggara. Sekitar 2 juta dari 7,3 perempuan Indonesia berusia di bawah 15 tahun sudah menikah dan putus sekolah. Jumlah itu diperkirakan naik menjadi 3 juta orang pada tahun 2030. Survei Demografi dan Kesehatan Indonesia 2012 menunjukkan bahwa 48 orang dari 1.000 remaja putri usia 15-19 tahun sudah melahirkan (Kompas, 2015).

Dalam konteks perundang-undangan, batasan tentang usia anak dipahami sebagai usia sejak lahir sampai akhir masa remaja. Definisi umur anak dalam Undang-undang Pemilu Nomor 10 Tahun 2008 pasal 19 ayat 1 adalah hingga berusia 17 tahun. Sementara itu, UU Perkawinan Nomor 1 Tahun 1974 menjelaskan bahwa batas usia minimal menikah bagi perempuan adalah 16 tahun dan lelaki adalah 19 tahun. Definisi anak berdasarkan UU Nomor 23 Tahun 2002 adalah seseorang yang belum berusia 18 tahun, termasuk anak yang masih berada dalam kandungan. Pernikahan anak didefinisikan sebagai pernikahan yang terjadi sebelum anak mencapai usia 18 tahun, sebelum anak matang secara fisik, fisiologis, dan psikologis untuk bertanggung jawab terhadap pernikahan serta anak yang dihasilkan dari pernikahan tersebut (Yayasan Kesehatan Perempuan, 2017). Dengan demikian, dapat dikatakan bahwa seseorang yang menikah pada saat masih di bawah usia 18 tahun bisa dikategorikan sebagai perkawinan usia dini.

Merujuk pada tingginya gap antara masyarakat lokal dan fakta permasalahan riil terkait dengan pernikahan dini, penanganan secara partisipatif masalah perkawinan usia dini penting untuk dijadikan sebagai prioritas. Permasalahan ini muncul pada wilayah-wilayah perdesaan yang belum sepenuhnya tersentuh program pembangunan secara baik, tepatnya pada wilayah dengan tingkat pendidikan rendah, kemiskinan akut, dan tradisi-tradisi yang bertentangan dengan kebutuhan zaman modern. Sebuah desa di Temanggung dipilih untuk menjadi sasaran penelitian ini. Hasil observasi awal menunjukkan bahwa desa ini memiliki tingkat perkawinan usia dini yang sangat tinggi. Sementara itu, umumnya, masa pascapernikahan memunculkan berbagai masalah sosial dan ekonomi, mengingat anak-anak yang telah menikah ini mengalami penambahan beban sosial-ekonomi karena adanya kewajiban-kewajiban sosial. Berdasarkan observasi awal kami, alasan ekonomi dan sosial-kebudayaan menjadi alasan seseorang dinikahkan

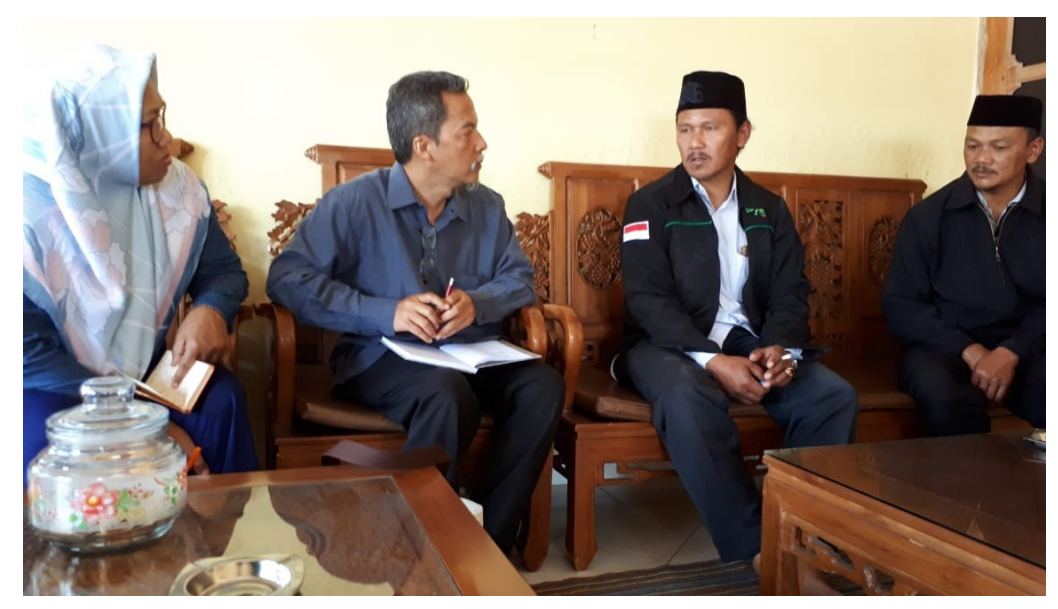

Gambar 1. Assessment awal kegiatan PkM. 
secara dini. Oleh karena itu, tidak salah apabila pernikahan anak ini sering dijumpai di kalangan keluarga miskin atau rentan secara ekonomi, meskipun terjadi pula di kalangan keluarga ekonomi atas. Pernikahan anak membuat keluarga, masyarakat, bahkan negara mengalami kesulitan untuk melepaskan diri dari jerat kemiskinan. Hal ini menyebabkan kualitas kesehatan dan kesejahteraan, baik anak maupun keluarga dan lingkungannya, tetap rendah.

Selain melibatkan sejumlah pengajar dari Departemen Antropologi, kegiatan ini juga melibatkan secara aktif para pamong, tokoh masyarakat, orang tua, PKK, ibu-ibu muda yang menikah di usia dini, pemuda-pemudi, siswa SMP, siswa SMA, remaja masjid, dan kelompok pengajian. Tujuannya adalah agar sasaran program mampu mengidentifikasi aspek penyebab dan dampak akibat perkawinan usia dini, mengenalkan peraturan perundangan perkawinan, dan merumuskan rekomendasi-rekomendasi bagi elemen-elemen masyarakat lokal sebagai upaya mencegah terjadinya perkawinan usia dini di desa sasaran. Untuk mencapai tujuan itu, kegiatan ini melakukan sejumlah sarasehan yang berfokus pada diskusi untuk mencari jalan keluar apabila terjadi perkawinan dini di lingkungan tempat tinggal mereka. Jalan keluar yang diambil didasarkan pada dialog antargenerasi yang sifatnya memihak kedua belah pihak, baik laki-laki maupun perempuan.

\section{Tujuan dan Sasaran Kegiatan}

Tujuan dan sasaran kegiatan dalam program $\mathrm{PkM}$ ini secara ringkas kami rumuskan dalam tabel berikut.

Tabel 1. Tujuan dan Sasaran Kegiatan PkM

\begin{tabular}{|c|l|}
\hline \multirow{3}{*}{ Goals } & $\begin{array}{l}\text { Tersedianya hasil rencana aksi secara partisipatoris tentang strategi } \\
\text { penanggulangan perkawinan usia dini di Desa Wonotirto, Kecamatan Bulu, } \\
\text { Kabupaten Temanggung, Jawa Tengah. }\end{array}$ \\
\hline \multirow{5}{*}{ Objective } & $\begin{array}{l}\text { Meningkatkan kemampuan masyarakat sipil Desa Wonotirto dalam } \\
\text { mengidentifikasi permasalahan sosial, khususnya terkait dengan perkawinan } \\
\text { usia dini. }\end{array}$ \\
\cline { 2 - 3 } & $\begin{array}{l}\text { Meningkatkan peran masyarakat sipil dalam mewujudkan pelaksanaan } \\
\text { dokumen rencana aksi penanggulangan perkawinan usia dini. }\end{array}$ \\
\hline \multirow{5}{*}{ Outcome } & $\begin{array}{l}\text { 1. Elemen masyarakat sipil memiliki kemampuan melakukan assessment } \\
\text { partisipatif kondisi masyarakatnya. } \\
\text { 2. Meningkatnya komitmen masyarakat untuk mengeliminasi perkawinan } \\
\text { dini di masyarakat. } \\
\text { 3. Meningkatnya kesadaran masyarakat sipil dalam membangun sinergi } \\
\text { dan collective action dengan elemen lain dalam upaya menanggulangi } \\
\text { perkawinan usia dini. }\end{array}$ \\
\cline { 2 - 3 } & \begin{tabular}{l} 
Tersedianya dokumen rencana aksi dan dokumen sosialisasi. \\
\hline
\end{tabular} \\
\hline
\end{tabular}




\begin{tabular}{|c|c|}
\hline \multirow[t]{2}{*}{ Kegiatan PkM } & $\begin{array}{l}\text { Pelatihan rapid assessment, pelatihan analisis situasi, dan pembuatan rencana } \\
\text { aksi. }\end{array}$ \\
\hline & Pelatihan dan pendampingan singkat pengembangan media sosialisasi. \\
\hline \multirow{2}{*}{ Sasaran Kegiatan } & $\begin{array}{l}\text { Kelompok masyarakat sipil seperti remaja, tokoh agama, tokoh masyarakat, } \\
\text { ibu-ibu PKK. }\end{array}$ \\
\hline & $\begin{array}{l}\text { Kelompok masyarakat sipil seperti remaja, tokoh agama, tokoh masyarakat, } \\
\text { ibu-ibu PKK. }\end{array}$ \\
\hline \multirow[t]{2}{*}{ Output } & $\begin{array}{l}\text { 1. Terselenggaranya } 1 \text { kali pelatihan. } \\
\text { 2. Jumlah peserta pelatihan setiap desa } 10 \text { orang. } \\
\text { 3. Terselenggaranya pendampingan. } \\
\text { 4. Jumlah peserta pendampingan } 10 \text { orang/desa. }\end{array}$ \\
\hline & $\begin{array}{l}\text { 1. Terselenggaranya } 2 \text { kali pelatihan. } \\
\text { 2. Jumlah peserta pelatihan } 10 \text { orang/desa. } \\
\text { 3. Jumlah peserta pendampingan } 10 \text { orang/desa. }\end{array}$ \\
\hline
\end{tabular}

\section{Pendekatan Pelaksanaan Program}

\section{Metode dan Tahap Pelaksanaan Kegiatan}

Tahapan kegiatan yang kami laksanakan di Desa Wonotirto, Bulu, Temanggung adalah sebagai berikut.

1. Identifikasi kelompok masyarakat sipil yang akan dilibatkan dalam pelatihan rapid assessment dan pelatihan analisis situasi serta pembuatan rencana aksi.

2. Pelaksanaan FGD dan sarasehan di Desa Wonotirto, baik untuk assessment maupun pelaksanaan perencanaan partisipatif, dilakukan sebanyak lima kali dengan peserta rata-rata 15 orang. Khusus pada kegiatan sarasehan dengan tokoh masyarakat, kegiatan diikuti oleh lebih dari 25 peserta. Kegiatan dilaksanakan pada siang dan malam hari, menyesuaikan ketersediaan waktu dari masyarakat sasaran.

3. Pelatihan dan pendampingan singkat pengembangan media sosialisasi. Dilakukan dengan diskusi bersama warga masyarakat, terutama orang muda, tentang sistem perkawinan dari perspektif budaya dan medis/kesehatan, khususnya bagaimana akibat atau potensi negatif yang muncul dari perkawinan usia dini.

Tahapan kegiatan tersebut terkait dengan sejumlah capaian dalam rangkaian kegiatan PkM di Desa Wonotirto, Bulu, Temanggung, yang antara lain adalah dokumen hasil assessment kondisi perkawinan usia dini, dokumen rencana aksi pencegahan perkawinan usia dini, dan dokumen sosialisasi pencegahan perkawinan usia dini. Kegiatan ini dikerjakan antara Juni-Oktober 2019, sementara kegiatan assessment awal dilakukan pada minggu pertama bulan Mei atau satu minggu sebelum bulan puasa. Mengenai sasaran utama dari kegiatan ini tertuju pada para remaja SMP dan SMA, ibu-ibu muda hasil perkawinan usia dini, PKK, dan kelompok pengajian yang ada di Desa Wonotirto, Kecamatan Bulu, Kabupaten Temanggung. Pemilihan desa sasaran kegiatan mengalami perubahan. Pada awalnya direncanakan di Desa Gandurejo, Kecamatan Bulu. Mengingat desa ini sedang menghadapi persiapan pemilihan kepala 
desa, tim memutuskan memindahkan lokasi kegiatan ke Desa Wonotirto. Pemindahan ini atas rekomendasi beberapa tokoh yang ditemui dengan alasan untuk menjaga situasi kondusif desa agar mereka fokus pada persiapan pemilihan kepala desa.

\section{Kegiatan Perencanaan Partisipatif}

Kegiatan ini merupakan pelatihan-pelatihan bertahap dengan dasar hasil assessment yang diarahkan untuk menghasilkan sebuah dokumen rencana pencegahan perkawinan usia dini yang dilakukan secara partisipatif. Pendekatan partisipatif dalam pelaksanaan program mengharuskan tim melakukan berbagai kegiatan secara terencana dan berulang. Kegiatan ini diawali dengan assessment awal di desa sasaran dan bertemu dengan individuindividu yang dilibatkan dalam kegiatan.

Kemudian, jadwal disusun sesuai dengan kesepakatan sasaran. Kegiatan penting kedua adalah pelaksanaan pelatihan assessment secara partisipatif bagi penyediaan data untuk mengembangkan rencana aksi penanganan perkawinan usia dini. Kegiatan selanjutnya adalah pengembangan media sosialisasi.

\section{Hamil di Luar Nikah}

Mbak Deta, usia 16 tahun 11 bulan, menikah pada April 2019. Sebenarnya Mbak Deta menikah dianggap pas berusia 17 tahun kurang 27 hari (menikah 3 April, lahir 30 April), sehingga belum memiliki KTP. Kasus mbak Deta adalah hamil di luar nikah. Saat wawancara dilangsungkan kandungannya sudah berusia 8 bulan. Suami lulusan SMP, sementara Deta putus sekolah saat SMK kelas 2. Sebenarnya orang tua berharap ia bisa menyelesaikan sekolah dulu, namun karena sudah hamil, mau tidak mau ya harus dinikahkan. Suami Deta saat ini, membantu mengerjakan ladang keluarga Mertua dan mengerjakan ladang keluarganya sendiri. Dulunya suami pekerjaannya juga mengurus ladang keluarga, bahkan sejak berpacaran. Ayah Mbak Deta cenderung membebaskan pergaulan Mbak Deta, terlebih saat itu keluarganya mengalami kesulitan ekonomi. Ayah Deta tadinya berdagang makanan, namun usahanya bangkrut dan tidak memiliki modal sama sekali untuk kembali berjualan, sehingga pemasukan utamanya adalah ladang..

Gambar 2. Contoh hasil assessment

\section{Pelaksanaan Program}

\section{Hasil Assessment Pernikahan Usia Dini di Desa Wonotirto, Temanggung}

Di bawah ini merupakan hasil pelaksanaan assessment pernikahan usia dini di masyarakat Desa Wonotirto, yang dikelompokkan dalam Kelompok Remaja, Pamong Desa/Toma, Pasangan Pernikahan Usia Dini, dan Kader KB.

\section{Kelompok Remaja}

1. Pernikahan dini didefinisikan sebagai pernikahan remaja di usia $14-16$ tahun, yang pada usia SMP, mereka sudah berpacaran. Alasan pernikahan dini umumnya karena kecelakaan; kurang kasih sayang orang tua; dijodohkan; pergaulan bebas; pengaruh video/film dewasa/free sex; kurang pengawasan orang tua. 
2. Penyebab munculnya pernikahan dini: pacaran dini, menonton "video panas", ingin melakukan hubungan seks, atau hamil. Hal ini didukung situasi rumah kosong karena orang tua pergi ke ladang. Remaja dianggap berpikiran pendek, umumnya setelah lelah bekerja, mereka membayangkan indahnya perkawinan sehingga menginginkan menikah meski usia masih muda.

3. Akibat pernikahan dini: kesenjangan ekonomi (cekcok akibat masalah ekonomi), perselingkuhan, perceraian. Ego masing-masing pasangan kuat dan kematangan belum ada. Itulah yang menjadi akar perceraian. Beberapa jalan keluar menghadapi kesenjangan ekonomi adalah istri menjadi TKW di luar negeri.

4. Pencegahan pernikahan dini: pentingnya peningkatan pengetahuan tentang kesehatan reproduksi/seksualitas, pendidikan seks bagi remaja, kegiatan bagi remaja yang positif, sosialisasi tentang pendidikan seks oleh orang tua dan tokoh masyarakat karena anak masih menurut dengan orang tua.

\section{Kelompok Pamong Desa/Toma}

1. Pernikahan usia dini adalah pernikahan pada umur gadis dan/atau jejaka 14-16 tahun, tetapi orang Wonotirto menganggapnya sebagai hal biasa, tidak ada masalah dengan pernikahan usia seperti itu karena sudah menjadi kebiasaan secara turun-temurun. Bagi mereka, hal ini aman-aman saja dan tidak bermasalah. Mungkin ada yang menjadi masalah ketika itu terkait dengan ekonomi atau keharmonisan rumah tangga, tetapi ini tidak banyak terjadi. Mereka menikah umumnya karena saling mencintai. Orang tua yang memiliki anak gadis berumur $20-25$ tahun dan belum menikah akan malu karena anaknya kasep/kedaluwarsa/kebablasen membujang. Pernikahan dini akan mengakibatkan kemandirian pasangan kurang karena semuanya masih ditanggung oleh orang tua perempuan (prinsip mangan ora mangan kumpul), pihak laki-laki tidak dituntut harus menafkahi istrinya.

2. Faktor penyebab pernikahan dini sekarang ini adalah internet dan ponsel, salah pergaulan, lepas kendali orang tua, dan moral agama yang bersangkutan kurang kuat.

3. Di pedesaan ada faktor orang tua dalam pernikahan dini, misalnya anak perempuan akan dikeluarkan dari sekolah oleh orang tuanya asal sudah ada yang melamar. Orang desa setia pada satu pasangan seperti merpati. Faktor orang tua juga sering berperan, yaitu menjodohkan anaknya dengan pilihan orang tua/dijodohkan. Asal kedua orang tua sepaham dalam rembugan, perjodohan akan lanjut dengan pernikahan tanpa melalui pacaran. Alasan pernikahan dini lainnya adalah bahwa orang tua khawatir anak mengalami kehamilan sehingga mereka berpikir lebih baik cepat dinikahkan guna menghindari zina.

4. Dulu, anak gadis "diperik muda" alias dinikahkan cepat, tetapi sekarang dikuliahkan dulu, menunggu lulus, baru menikah. Orang desa memilih menikah dengan orang sedesa, jarang yang mendapat pasangan dari desa lain (hampir $70 \%$ mendapat tetangga/peknggo). Pola tempat tinggal setelah menikah adalah ikut dengan keluarga istri (nututi kemul). Meski laki-laki ikut dengan istri, lakilaki harus banyak modalnya untuk bayar tukon, ijab, dan lainnya.

5. Nikah muda secara budaya berarti adanya tambahan tenaga kerja yang muda 


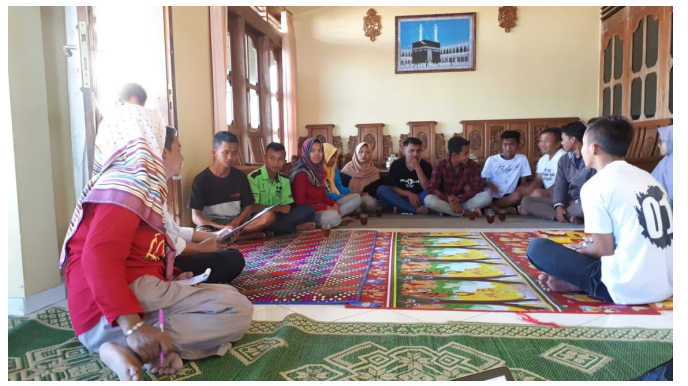

Gambar 3. Forum diskusi dengan remaja.

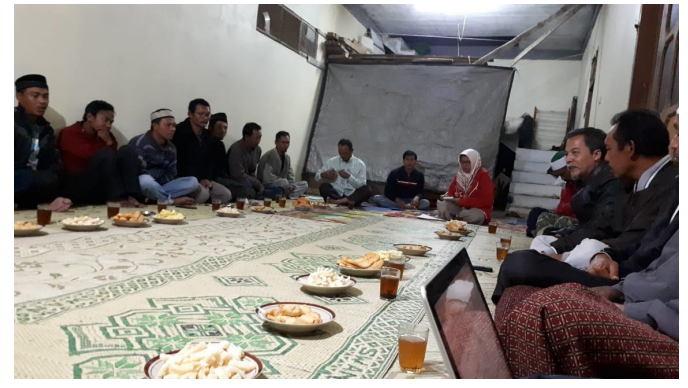

Gambar 4. Forum diskusi dengan tokoh masyarakat.

sebab mereka butuh tenaga muda yang baru, yaitu dari menantu. Jika tenaga kuat, usaha pertanian mereka akan maksimal. Saat panen tembakau bulan November/Desember, banyak orang mantu mendadak. Mereka membuat pesta yang meriah dengan hiburan organ tunggal, sedangkan pada zaman dahulu yang disukai adalah wayang/ketoprak. Alasan orang tua menikahkan anak, antara lain, adalah mumpung ada rezeki, menikahlah. Aturan bobot bibit bebet tetap menjadi patokan. Namun, jika anak harus menikah muda, orang tua berani mengambil risiko dengan cara beli surat/beli syarat nikah, yaitu umur anak dinaikkan. Dalam hal ini berarti orang tua sendiri yang menabrak aturan pemerintah terkait dengan batas usia pernikahan. Pamong setempat terpaksa melayani permintaan warga dalam hal manipulasi umur sebab pamong sering dibodohi oleh warga. Istilah "jujur mateni, goroh nguripi" berlaku di sini.

6. Solusi yang ditempuh bagi orang desa: warisan diberikan secara lebih dini, tanah dijual, dan kemudian dibagi. Mengingat umumnya mereka merupakan petani dengan sistem tanaman musiman maka strategi gali lubang tutup lubang banyak dijalankan guna menutup biaya pesta atau biaya sosial lainnya. Berbeda jika orang tuanya kaya, anak yang menikah dini satu tahun kemudian akan dilepas untuk mandiri dengan bekal modal dari orang tua.

\section{Kelompok Pasangan Pernikahan Usia Dini}

1. Dorongan menikah dini disebabkan oleh beberapa hal: daripada pacaran, lebih baik menikah langsung; hanya membayangkan yang menyenangkan dalam perkawinan; ada yang menafkahi; ingin mempunyai keturunan; rasa tanggung jawab (pria). Jika menikah muda, biaya dapat ditanggung orang tua. Kesulitan persyaratan diatasi dengan sidang dahulu di KUA, ditanya penghasilan/ kesanggupan menafkahi, restu orang tua, kemudian menembak surat seharga Rp2.000.000,00.

2. Pada pernikahan muda tetap dilakukan lamaran, yakni pengantin laki-laki datang disertai orang tua kepada orang tua pihak perempuan. Jika pasangan itu satu desa, maharnya biasanya berupa uang dan pihak perempuan diminta untuk belanja perhiasan sendiri dari uang yang telah diberikan sebesar Rp5.000.000,00 atau Rp10.000.000,00, tergantung pada harga panen tembakau. Jika mereka berasal 
dari desa yang berlainan, tetap ada seserahan. Orang tua akan menanggung atau membantu biaya upacara perkawinan. Setelah berumah tangga, mereka tinggal di rumah pihak istri dengan cara rumah disekat. Jika secara ekonomi pasangan belum mapan, mereka akan tinggal wira-wiri di tempat pihak pria dan juga wanita. Meski pekerjaan mandiri, rumah tetap bersatu dengan mertua. Dalam hal menyumbang manten masih ditanggung oleh mertua. Biaya pendidikan dan kesehatan anak ditanggung sendiri. Jika musim tembakau tiba, anak biasanya cepat mandiri atau memisahkan diri dari tempat tinggal orang tua karena secara ekonomi mereka sudah kuat. Tradisi di desa setelah anak menikah adalah diberi hak untuk menggarap tanah.

3. Jika sudah sah menikah, mereka tidak malu jika berduaan. Jika akan merantau pun lebih mudah karena sudah sah menikah. Pada umumnya, pasangan menikah muda berpikiran cepat matang. Hal ini didukung dengan adanya fakta bahwa rata-rata pasangan muda dalam satu tahun perkawinan sudah memiliki anak. Anak yang lahir akan dititipkan simbah atau dibawa ke ladang. Petani di desa umumnya tidak bercita-cita tinggi, yang terpenting adalah bekerja. Santai dan menerima rezeki Tuhan.

4. Persiapan menikah: mental, kedewasaan/tanggung jawab, sanggup menafkahi, mengikuti alur, tidak kaku, menurut kepada mertua.

5. Cekcok dalam perkawinan muncul karena kecemburuan, berbeda pilihan/ pendapat/ hobi, permasalahan ekonomi, permasalahan anak, masalah penggunaan waktu.

6. Harapan mereka sebagai orang tua terhadap anak: jangan menjadi petani, harus lebih baik dari orang tua, menjadi orang pintar. Muncul kesadaran investasi melalui kerja keras di bidang pertanian sehingga anak didorong untuk sekolah/ kuliah dan Yogyakarta masih menjadi tujuan tempat kuliah. Jika ada kesulitan dalam membiayai kuliah, orang tua akan meminjam biaya kepada saudara, kemudian nanti dikembalikan. Hasil panen sayuran juga ditabung dalam bentuk emas dan tabungan di bank.

\section{Kelompok Kader KB}

1. Anak zaman sekarang berbeda dengan pemuda pada masa orang tuanya. Saat ini pengaruh ponsel sangat banyak dan juga mudahnya akses terhadap hal-hal yang berbau pornografi, salah pergaulan sehingga anak perempuan mengalami kehamilan di luar nikah, anak SMP kelas II atau III sudah hamil dan menikah. Hal itu sedikit banyak berbeda dengan zaman orang tua mereka. Ponsel bagi anak-anak remaja menjadi barang nomor satu yang harus dimiliki. Meski bersifat merusak jika disalahgunakan, orang tua tetap membelikan ponsel untuk anaknya.

2. Laki-laki yang menikahi gadis muda di Wonotirto umumnya merupakan lakilaki dewasa (80\%), sudah bekerja/mencari uang, bisa berasal dari satu desa atau berbeda desa, kemudian melamar gadis Wonotirto. Jika ada laki-laki yang sudah kula nuwun, orang tua di Wonotirto umumnya takut apabila menolak lamaran dan biasanya pasti segera diberikan. Orang tua, khususnya ibu, akan menuruti keinginan anaknya. Jika anak ingin menikah, mereka yang menikah 
muda umumnya didasarkan rasa saling suka satu dengan lainnya.

3. Gadis yang menikah muda merasa terkekang setelah menikah, sering cekcok dengan pasangan karena masalah ekonomi, pemikiran mereka belum panjang, rasa tanggung jawab pada suami belum ada, beberapa dari mereka berakibat perceraian. Di Dusun Grubug, dua pasangan muda menikah, kemudian bercerai. Kasus KDRT terjadi pada pasangan muda, kemudian bercerai sehingga mereka takut dan trauma untuk menikah lagi. Tugas simbah bertambah berat sebab meski ibu muda itu mau menyusui, pengasuhan anak tetap diserahkan ke simbah sepenuhnya.

4. Orang tua dalam hal pengasuhan terhadap anak-anak remaja tidak kurangkurangnya memberi nasihat, tetapi sering kali ego anak lebih tinggi sehingga tidak dapat dinasihati terkait dengan pola pergaulannya. Beberapa dusun di Wonotirto memiliki sinyal ponsel yang bagus dan jalan aspal yang mulus sehingga memudahkan muda-mudi berpacaran dengan pemuda desa lain. Meski gadis mereka telanjur hamil, misalnya tujuh bulan, mereka tetap periksa kesehatan/ ANC meski baru dimulai pada kehamilan empat bulan.

5. Yang dipikirkan pasangan muda dengan pernikahan dini adalah senang-senang dulu saat resepsi, menjadi manten itu enak, setelah menikah masih hidup bersama orang tua, tetapi setelah tanggung jawabnya meningkat, pemikiran akan berubah. Apabila mereka punya rumah sendiri, pemikiran akan berubah lebih bertanggung jawab. Pengalaman pasangan dini yang perkawinannya gagal sehingga menjadi janda dan menikah lagi selalu disampaikan oleh orang tua kepada anaknya. Nasihat ibu-ibu yang dahulu menikah muda kepada anak: "Aja kaya biyangane," dan bercita-citalah yang tinggi.

\section{Refleksi Capaian Program}

Assessment yang dilakukan sebagai dasar penanganan partisipatif masalah perkawinan usia dini di satu desa di Kabupaten Temanggung cukup krusial dan dapat menjadi prioritas, mengingat permasalahan ini banyak muncul di wilayah pedesaan Jawa. Tinjauan awal di desa ini menunjukkan bahwa tingkat perkawinan usia dini masih

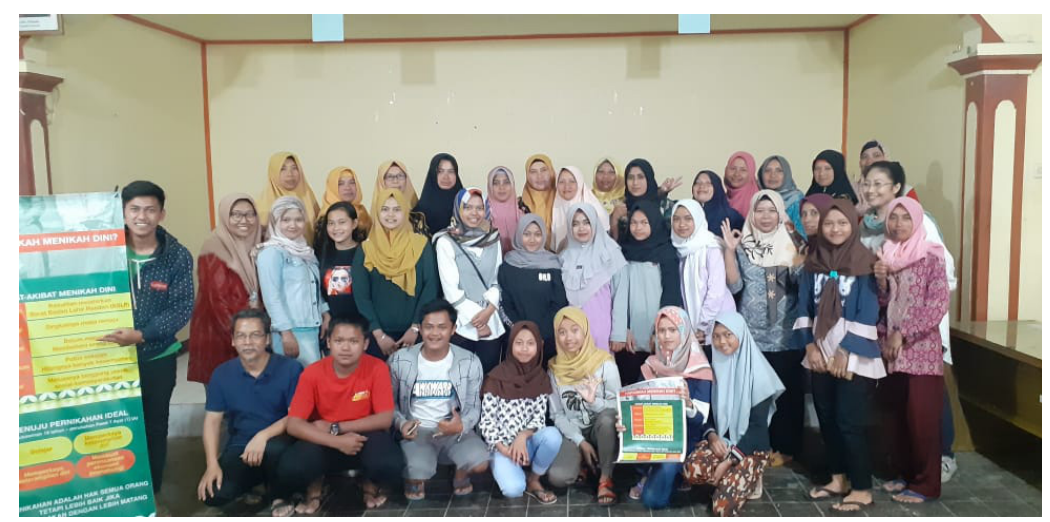

Gambar 5. Remaja Wonotirto berkomitmen menyebarkan hasil PkM ke remaja lain. 
sangat tinggi. Konsekuensi dari perkawinan dini yang terjadi di sana umumnya adalah munculnya berbagai masalah sosial (berupa perceraian dan perselingkuhan) serta ekonomi (ketergantungan terhadap orang tua). Pada aspek psikologis, anak-anak yang telah menikah ini mengalami penambahan beban sosial-ekonomi karena adanya kewajiban-kewajiban sosial yang belum saatnya. Di sini, alasan ekonomi dan sosialkebudayaan menjadi alasan seseorang dinikahkan lebih awal. Oleh karenanya, tidak salah apabila pernikahan usia dini ini sering membuat keluarga, masyarakat, bahkan negara mengalami kesulitan untuk melepaskan diri dari jerat kemiskinan dan hal ini tentunya menyebabkan kualitas kesehatan serta kesejahteraan keluarga menjadi rendah, baik bagi pihak anak maupun keluarga dan lingkungan sosialnya.

\section{Penutup}

Untuk mengatasi pernikahan usia dini, beberapa forum diskusi memberikan rekomendasi, antara lain, seperti (i) perlunya remaja difasilitasi untuk bisa membuat kegiatan positif sehingga waktu luangnya termanfaatkan dengan baik; (ii) perlunya pendidikan seks bagi remaja; (iii) meningkatkan peran orang tua dalam sosialisasi pendidikan seks; (iv) perlunya perangkat desa membuat sebuah kesepakatan/aturan (tertulis atau tidak tertulis) terkait dengan kebiasaan perkawinan dini sehingga diharapkan jumlah kasuskasus seperti itu akan menurun pada masa mendatang.

\section{Daftar Pustaka}

Kompas. (2015). "Pernikahan Dini Memicu Masalah". Dilansir dari https://nasional. kompas.com/read/2015/06/20/19312021/Pernikahan.Dini.Memicu.Masalah.

Plan Indonesia (Jakarta) and Center for Population and Policy Studies. (t.t.). Preliminary Findings. Situation Analysis of Child Marriage in Rembang, Grobogan, Soe, Sikka, Lembata, Indramayu, and Tabanan in Indonesia. Collaboration Research. Yogyakarta: Gadjah Mada University Press.

Priherdityo, Endro. (2016). "Pernikahan Usia Anak Masih Marak di Indonesia." CNN Indonesia. Dilansir dari https://www.cnnindonesia.com/gayahidup/20160723074431-277-146515/pernikahan-usia-anak-masih-marak-diindonesia.

UNICEF. (2001). "Early Marriage: Child Spouses." Innocenti Digest (7).

UNICEF. (2005a). Early Marriage: A Harmful Traditional Practice: A Statistical Exploration. The United Nations Children's Fund.

UNICEF. (2005b). Forum on Marriage and the Rights of Women and Girls 2001. The United Nations Children's Fund.

UNICEF. (2010). Progress for Children: Achieving the MDGs with Equity. Diunduh dari https://www.unicef.org/protection/Progress for Children-No.9 EN 081710.pdf.

United Nations. (1994). Declaration on the Elimination of Violence against Women. U.N. General Assembly. Geneva: United Nations.

Yayasan Kesehatan Perempuan. (2017). "Pernikahan Usia Dini dan Permasalahannya". Dilansir dari http://ykp2015.com/pernikahan-usia-dini-dan-permasalahannya/. 